\title{
MODEL PENGEMBANGAN SUMBER DAYA NELAYAN BERWAWASAN AGRIBISNIS DI KOTA BENGKULU
}

\section{MODEL OF RESOURCE DEVELOPMENT OF AGRIBUSINESS MINDED FISHERMEN IN THE CITY BENGKULU}

\author{
Sriyoto, dan Bambang Sumantri \\ Jurusan Sosial Ekonomi Pertanian Universitas Bengkulu
}

Globalization era characterized by increasingly open and integrated commodity markets both between countries and between regions including fishery commodities. This imply that an increasing of product quality through empowering fishing resource is a significant step to be able to enter an era of competition. This study aims to identify the performance of the fisherman resources, a partnership between fishermen and fish entrepreneurs, and formulate alternative development model of fisherman resource with agribusiness minded. The research method is based on the survey method (primary and secondary data). Descriptive methods, descriptive statistics, and methods of the Logical Framework Analysis (LFA) are used to analyse data. The results showed that the fishermen, in general, are in the productive age with the typology of the nuclear family; more than half of the fishermen have junior secondary education level; fishing experience is categorized long enough that 18.26 years; fishermen have the motivation to keep working as a fisherman and a hierarchy of compassion (safety needs) by 60\%; technical and managerial skills possessed by fishermen in general is quite good but the managerial aspects of fishing is still not good. Furthermore, most fishermen have high accessibility to the means of fishing, but only a few fishermen who use capital loans of non-formal institutions, mostly fishermen actively looking for information about fishing technology, relationship between the fishermen and fish processors/collectors is a patron client pattern, the market formed in the study area is oligopsonistic market, and net income of fishermen can be categorized enough. There are two alternative models of fisherman resources development with agribusiness minded: training model with a training for impact approach, and education model.

Key words: agribusiness, development model, fisherman resources

\section{PENDAHULUAN}

Kota Bengkulu memiliki potensi ikan tangkapan sebesar 145.334 ton per tahun namun kekayaan sumber daya alam kelautan ini belum dikembangkan secara serius dan investor pun belum tertarik untuk menanamkan modalnya di subsektor perikanan tangkap sehingga imbasnya kehidupan masyarakat nelayan di wilayah Kota Bengkulu masih saja tetap miskin. Ketidakberdayaan nelayan tradisional di daerah Kota Bengkulu dalam meningkatkan produksi 
tangkap terkendala pada masalah modal dan pada gilirannya mereka tidak mampu membeli peralatan modern. Berangkat dari kenyataan sumber daya nelayan di Kota Bengkulu maka kajian ini akan difokuskan kepada keragaan, pola kemitraan dan pengembangan sumber daya nelayan dalam kaitannya dengan kemitraan tersebut dan alternatif model pengembangan sumber daya nelayan yang berwawasan agribisnis dan di samping relatif masih terbatasnya kajian mengenai pengembangan sumber daya nelayan. Oleh karena itu, tujuan penelitian ini adalah mengidentifikasi keragaan sumber daya nelayan, mengidentifikasi pola kemitraan dan pengembangan sumber daya nelayan dalam kaitannya dengan kemitraan, dan merumuskan alternatif model pengembangan sumber daya nelayan berwawasan agribisnis.

\section{METODE PENELITIAN}

Metode yang digunakan dalam penelitian ini adalah metode survai. Metode ini adalah suatu metode penelitian di mana informasi didapatkan secara langsung dari individu/kelompok dalam populasi (Bailey 1987 dan Dane 1990).

Penelitian dilakukan di Kecamatan Kampung Melayu Kota Bengkulu di mana ditentukan secara sengaja (purposive) dengan pertimbangan di lokasi ini banyak terdapat nelayan untuk Kota Bengkulu. Sampel dalam penelitian ini diambil sebanyak 30 orang dari populasi. Sampel nelayan tersebut dimaksud pada tahun 2014. Populasi dalam penelitian ini adalah nelayan dan pengolah ikan kering skala rumah tangga. Sampel lain adalah pedagang pengumpul yang diidentifikasi dengan menggunakan metode Snowball.

Data yang dikumpulkan berupa data primer dan sekunder. Data primer merupakan data yang secra langsung didapat dari responden/sampel terpilih dengan melakukan wawancara berdasarkan quesioner yang telah dipersiapkan terlebih dahulu. Dalam penelitian ini, data primer yang dikumpulkan meliputi data-data yang berkaitan dengan atribut yang melekat pada diri responden, deskripsi variabel eksternal (peubah eksternal). Sementara itu, data sekunder didapatkan dari data-data yang sudah ada sebelumnya seperti dari kantor lurah, kecamatan, dan instansi lain yang terkait dengan penelitian ini.

Penggunaan metode Participatory Rural Appraisal (PRA) digunakan untuk mendapatkan informasi yang bersifat kualitatif. Pengumpulan informasi menggunakan pendekatan Focus Group Discussion (FGD) dilakukan untuk menjaring data/informasi lebih detail mengenai opini nelayan yang menjadi fokus utama penelitian ini. Dalam FGD ini pesertanya adalah responden nelayan aparat pemerintahan (lurah dan kecamatan), agen pembaharu (penyuluh perikanan), dan tokoh-tokoh masyarakat nelayan. 
Teknik analisis data/informasi yang digunakan dalam penelitian ini secara garis besar terdiri dari dua jenis yaitu deskriptif dan statistik deskriptif dengan menggunakan uji tabel dan uji grafik.

\section{Deskriptif (descriptive)}

Analisis deskriptif digunakan untuk menjelaskan secara menyeluruh (komprehensif) tentang data dan informasi yang diperoleh dari lapangan. Dalam analisis deskriptif ini sebaran data kuantitatif yang diperoleh disajikan melalui proses kodetifikasi, kategorisasi, interpretasi, pemaknaan, dan abstraksi (Meleong, 2004 dan Sukandar rumidi, 2004). Analisis deskriptif dilakukan dengan tujuan untuk mengungkap fenomena dari obyek yang dikaji. Dengan analisis deskriptif akan diperoleh gambaran tentang sesuatu yang lazim atau unik dalam suatu masyarakat nelayan serta gambaran tentang variasi-variasi yang ada dalam masyarakat nelayan khususnya yang berkaitan dengan obyek dan subyek penelitian ini. Dalam analisis deskriptif ini lebih dititik beratkan pada upaya untuk menjelaskan karakteristik dari responden berdasarkan peubah internal, seperti karakteristik demografi, tingkat pendidikan, pengalaman mengelola usaha, motivasi dalam berusaha, dan kemampuan teknis dan manajerial.

\section{Statistik deskriptif}

Analisis ini akan digunakan untuk mengkaji pola kemitraan antara nelayan dengan pengusaha ikan sehingga akan diperoleh gambaran secara menyeluruh mengenai bentuk-bentuk pola kemitraan yang terjadi khususnya dalam rangka pengembangan sumber daya nelayan di Kota Bengkulu. Peubah eksternal yang akan digunakan untuk mengkaji pola kemitraan meliputi aksesibilitas terhadap sarana penangkapan, aksesibilitas tingkat sarana pemodalan, aksesibilitas terhadap sumber informasi, hubungan usaha nelayan dan perusahaan serta aspek pasar.

\section{Metode LFA (Logical Framework Analysis)}

Metode utama untuk mendapatkan desain pengembangan sumber daya nelayan yang spesifik adalah LFA (Logical Framework Analysis). LFA dipergunakan untuk menyusun model pengembangan sumber daya nelayan dengan berbasis pada analisis logis serta berbagai kondisi dan asumsi-asumsi tertentu. LFA adalah proses analisis untuk struktur dan sistematisasi suatu proyek atau ide program. Lebih lanjut, aplikasi LFA melibatkan analisis stakeholder, analisis masalah, menetapkan tujuan dan strategi seleksi suatu proyek atau program. Dengan demikian, LFA akan menghasilkkan bentuk kegiatan yang dapat diverifikasi atau dievaluasi. 
Dalam rancangan model pengembangan sumber daya nelayan akan difokuskan kepada model pelatihan, model penugasan, dan model pendidikan.

\section{HASIL DAN PEMBAHASAN}

\section{Deskripsi peubah internal nelayan}

\section{Karakteristik demografi}

Dari hasil penelitian diperoleh bahwa berdasarkan umur nelayan ternyata berada di kisaran usia produktif yaitu rata-rata usia nelayan 40 tahun dengan kisaran 25-60 tahun. Hal ini didukung oleh pendapat Mubyarto (1989), di mana usia produktif berada pada kisaran usia 15-64 tahun. Dengan usia produktif ini nelayan memiliki semangat dan tenaga yang kuat dalam usaha melakukan penangkapan ikan, sehingga diharapkan pada usia produktif dan didukung oleh lamanya pengalaman melaut atau sebagai nelayan dapat mendukung kegiatan melaut untuk tercapainya usaha penangkapan yang optimal. Lebih lanjut Mubyarto (1989) berpendapat bahwa seseorang pada usia produktif akan memberikan hasil yang maksimal jika dibandingkan dengan usia di bawah atau di atas usia produktif.

Jumlah anggota keluarga nelayan rata-rata 4,6 jiwa, hal ini mengindikasikan tipologi ukuran keluarga nelayan adalah orang tua berikut tiga anak (nuclear family). Demikian juga halnya dengan jumlah usia produktif dalam keluarga nelayan rata-rata 2,96 jiwa artinya dalam satu keluarga nelayan memiliki usia produktif yaitu orang tua dan satu orang anak.

\section{Tingkat pendidikan}

Keberhasilan seorang nelayan dalam upaya melakukan penangkapan ikan faktor pendidikan formal akan berpengaruh, karena tingkat pendidikan akan menentukan kemampuan seseorang dalam menyerap suatu informasi dan inovasi (Anna, 2004). Tingkat pendidikan yang dimiliki oleh nelayan merupakan faktor penunjang keberhasilan nelayan dalam bekerja, karena faktor pendidikan formal akan mempengaruhi pola pikir, tindakan dan perbuatan terhadap segala sesuatu yang berkaitan dengan usaha penangkapan ikan oleh nelayan (Mardani, 2009).

Hasil penelitian menunjukkan bahwa tingkat pendidikan nelayan bervariasi dari tingkat pendidikan tidak tamat SD sampai pada tingkat pendidikan SLTA. Sebagian besar nelayan menamatkan pendidikannya pada jenjang pendidikan SLTP atau lama pendidikan selama 9 tahun yaitu sebesar 63,3\%. Dalam kaitannya antara tingkat pendidikan nelayan dan ditambah dengan pengalaman melaut bagi nelayan akan mempengaruhi produktivitas jumlah tangkapan. Artinya semakin tinggi pendidikan formal dan pengalaman 
melaut yang semakin lama, maka produktivitas jumlah tangkapan akan semakin tinggi. Dengan berdasarkan latar belakang tingkat pendidikan yang dimiliki oleh nelayan, kemudian ditelusuri lebih lanjut aspirasi nelayan mengenai pendidikan anak-anaknya (anggota keluarga), diperoleh gambaran bahwa nelayan ingin menyekolahkan anak-anaknya pada jenjang pendidikan yang lebih tinggi yakni sebesar $80 \%$. Namun ada sebagian nelayan yang berpendapat bahwa bagi anak-anak nelayan cukup tingkat pendidikan yang tidak terlalu tinggi.

\section{Pengalaman sebagai nelayan}

Pengalaman nelayan dimasukkan sebagai peubah yang mempengaruhi performansi nelayan dengan asumsi bahwa semakin lama seseorang menggeluti pekerjaannya maka performansi terhadap pekerjaan tersebut akan semakin baik. Keberhasilan di dalam upaya penangkapan ikan oleh nelayan tidak hanya ditunjang oleh faktor pendidikan formal dan non formal, namun ada faktor lain yang mendukung keberhasilan dalam upaya penangkapan ikan yakni pengalaman dalam usaha penangkapan ikan. Pengalaman ini dapat membantu nelayan dalam pengambilan keputusan, dan seorang nelayan akan cenderung belajar dari pengamalan sehingga memiliki gambaran tentang apa yang akan dilakukan bagi peningkatan produktivitas tangkapan ikan pada waktu-waktu berikutnya.

Hasil penelitian menunjukkan bahwa rataan pengalaman nelayan adalah 18,26 tahun, hal ini mengindikasikan bahwa pengalaman atau mata pencaharian sebagai nelayan dapat dikategorikan cukup lama. Dengan cukup lamanya pengalaman nelayan ini nelayan akan dapat menyusun perencanaan dalam upaya penangkapan ikan yang lebih baik dan tepat, serta lebih bijak dalam menyikapi setiap perubahan yang terjadi baik yang mendatangkan keuntungan maupun kerugian dari hasil kegiatan usaha penangkapan ikan tersebut.

\section{Motivasi dalam usaha}

Dalam pengkajian ini teori motivasi yang dipakai adalah teori yang dikembangkan oleh Maslow, karena pendekatan Maslow cocok dipergunakan pada kelompok masyarakat yang termasuk ke dalam lapisan menengah ke bawah (Thoha, 1995). Ada lima skala pengukuran motivasi menurut Maslow yaitu: 1) pemenuhan kebutuhan fisik; 2) pemenuhan rasa aman; 3) pemenuhan rasa kasih sayang; 4) keinginan untuk dihargai; dan 5) pemenuhan aktualisasi diri. Di dalam teori Maslow merasakan bahwa ada nilai tertentu dalam menggolongkan kebutuhan-kebutuhan, dan terdapat pula suatu perbedaan antara kebutuhan-kebutuhan dalam tatanan paling bawah dengan kebutuhan-kebutuhan dalam tatanan paling atas (Thoha, 1995). 
Dari hasil pengamatan diketahui bahwa motivasi nelayan untuk tetap bekerja sebagai nelayan, pada umumnya berada pada hierarki (skala) memenuhi rasa kasih sayang (safety needs) yakni sebesar 60\%. Namun demikian masih ada sebagian nelayan yang mempunyai motivasi atau berada pada hierarki memenuhi kebutuhan fisik (physiological needs). Dengan demikian dapat disimpulkan bahwa motivasi untuk menjadi nelayan tidak lagi sematamata untuk memenuhi kebutuhan dari sandang, pangan, dan papan. Hal ini terbukti dari hasil pengamatan terhadap kondisi rumah yang dimiliki, di mana hampir seluruh nelayan memiliki rumah permanen dengan furniture yang baik.

\section{Kemampuan teknis dan manajerial}

Pengertian kemampuan dititikberatkan pada pengetahuan yang dimiliki nelayan khususnya pengetahuan penangkapan dan penanganan hasil tangkapan serta pengetahuan manajerial. Informasi mengenai pengetahuan teknis diketahui dengan kegiatan yang dilakukan oleh nelayan dalam penangkapan ikan serta penanganan hasil tangkapan oleh nelayan. Hasil penelitian menunjukkan bahwa kegiatan penangkapan ikan yang dilakukan oleh nelayan secara umum sudah cukup baik. Hal ini tercermin dari persiapan/pembawaan bekal untuk melaut, pemasangan jaring, serta mencari lokasi-lokasi yang diperkirakan banyak terdapat ikan. Kondisi ini berarti para nelayan telah mempersiapkan teknik penangkapan yang cukup baik. Namun dari sisi processing (penangkapan ikan yang sudah ditangkap) hanya sebesar $15 \%$ nelayan yang melakukan pengolahan hasil dan kebanyakan dari nelayan yang melakukan pengolahan ikan sumber bahan baku dari pembelian, kemudian baru dilakukan processing/pengolahan ikan.

Untuk mengidentifikasi pengetahuan manajerial dilakukan dengan menggunakan daftar pertanyaan baku yaitu: pengambilan keputusan, penyusunan rencana, evaluasi, komunikasi, dan organisasi. Hasil penelitian menunjukkan bahwa nelayan yang membuat perencanaan sebelum melaut hanya sebesar $40 \%$. Hal ini dikarenakan nelayan belum mengetahui apa peranan, fungsi, dan manfaat dari perencanaan sebelum melaut. Untuk itu ke depan diperlukan bimbingan teknis mengenai peran perencanaan bagi para nelayan. Dalam pengambilan sebelum melaut yang dilakukan oleh nelayan sebagian besar yaitu $80 \%$ nelayan pengambilan keputusan dilakukan oleh nelayan sendiri, sedangkan $76,6 \%$ nelayan melakukan pengambilan keputusan bersama antara nelayan dan istri. Artinya kondisi ini merupakan hal yang baik dalam rumah tangga nelayan, karena dengan melibatkan istri di dalam pola pengambilan keputusan sebelum melakukan kegiatan penangkapan ikan atau dengan kata lain terjadi kesejajaran antara nelayan dengan istri di dalam upaya melakukan usaha penangkapan ikan. Dalam komunikasi dan organisasi, setiap orang akan menjadi anggota organisasi. Setiap orang setuju bahwa komunikasi di antara mereka dan antara mereka dengan lingkungannya, merupakan 
sumber kehidupan dan kedinamisan organisasinya (Thoha, 1995). Setiap teori organisasi yang tuntas, komunikasi akan menduduki suatu tempat yang utama karena susunan, keluasan, dan cakupan organisasi secara keseluruhannya ditentukan oleh teknik komunikasi. Komunikasi adalah suatu proses sosial yang mempunyai relevansi terluas di dalam memfungsikan setiap kelompok organisasi atau masyarakat.

Hasil penelitian menunjukkan bahwa komunikasi yang dilakukan oleh nelayan dengan sesama anggota nelayan atau anggota masyarakat sebelum melakukan kegiatan penangkapan ikan, hanya sebesar 36,6\%. Keadaan ini mengindikasikan bahwa nelayan atau masyarakat nelayan jarang melakukan sharing kepada anggota masyarakat nelayan dan menurut keyakinan nelayan bahwa pengalaman melaut akan merupakan hal yang lebih menentukan keberhasilan dalam usaha penangkapan ikan.

Evaluasi adalah proses pengecekan yang meliputi kegiatan-kegiatan untuk membandingkan hasil yang sebenarnya dengan hasil yang diperkirakan sebelumnya. Kegiatan ini berupa pelaporan dan penilaian peningkatan atau perbaikan. Secara logis evaluasi dapat menentukan bagaimana hasil sebenarnya apakah sesuai atau tidak dengan hasil yang diperkirakan, sehingga dapat menentukan tindakan yang harus diambil selanjutnya (Garrett and Silver, 1968).

Dalam penelitian ini evaluasi yang dimaksud adalah proses pengecekan atau penilaian yang dilakukan oleh nelayan terhadap jumlah produksi tangkapan ikan dengan jumlah produksi tangkapan yang diperkirakan. Hasil pengamatan menunjukkan bahwa hanya sebesar $40 \%$ nelayan melakukan kegiatan evaluasi setelah kegiatan penangkapan ikan dilakukan. Kondisi ini menggambarkan bahwa bagi nelayan kegiatan evaluasi belum merupakan hal yang penting di dalam kegiatan usaha penangkapan ikan.

\section{Deskripsi peubah eksternal nelayan}

\section{Aksesibilitas terhadap sarana penangkapan}

Kemudahan memperolah sarana melaut merupakan salah satu faktor yang dapat memperlancar kegiatan nelayan di laut. kelengkapan sarana penangkapan ikan dalam hal ini meliputi: bahan bakar, oli, es, dan akomodasi melaut. Hasil penelitian menunjukkan bahwa sebesar $63,4 \%$ nelayan menyatakan mudah dalam memperoleh sarana penangkapan, sedangkan sebesar $36,6 \%$ nelayan menyatakan merasa sulit untuk mendapatkan sarana penangkapan. Kemudian memperoleh sarana penangkapan erat kaitannya dengan pola hubungan antara pengolah ikan (pengumpul) dengan nelayan. Dalam hal ini pengolah ikan (pengumpul) akan memberikan bantuan 
modal/kredit pengelolaan sarana penangkapan dan nelayan berkewajiban untuk menjual ikan tangkapannya kepada pengolah ikan (pengumpul).

\section{Aksesibilitas tingkat sarana permodalan}

Kemudahan untuk mendapat pinjaman (modal) usaha baik institusi formal (bank) maupun non formal merupakan salah satu faktor penentu yang dapat memperlancar kegiatan nelayan. Hasil penelitian menunjukkan bahwa sebesar 33,3\% nelayan menyatakan pernah mendapatkan pinjaman/modal usaha dari lembaga non formal, namun nelayan belum pernah meminjam dari institusi formal.

Berdasarkan pengakuan nelayan yang pernah meminjam modal usaha, dalam upaya mendapatkan modal nelayan menyatakan mudah dalam memperolehnya. Sedangkan sebesar $66,7 \%$ nelayan menyatakan tidak pernah meminjam modal usaha. Menurut pendapat nelayan apabila meminjam modal usaha akan menimbulkan beban dalam kegiatan melaut. Berdasarkan data yang dihimpun koperasi yang berada di lokasi kajian ternyata berperan banyak dalam membantu menambah pemodalan para nelayan namun nelayan belum memanfaatkan jasa perbankan dalam pemodalan. Hal ini disebabkan pinjaman modal dari instansi non formal cenderung tidak serumit instansi formal.

\section{Aksesibilitas terhadap sumber informasi}

Informasi memegang peranan dalam membentuk sikap keingintahuan seseorang, yaitu suatu sikap untuk mau menerapkan hal-hal baru (teknologi baru) lebih dahulu daripada orang lain. Aktivitas mencari informasi tentang ide-ide baru (inovasi teknologi) golongan masyarakat yang aktif biasanya lebih inovatif dibandingkan golongan masyarakat yang pasif (Mardikanto, 2010 dan Purwoko, 2009). Hasil kajian menunjukkan bahwa sebesar $80 \%$ nelayan mencari informasi mengenai teknologi penangkapan ikan, sedangkan sebesar $20 \%$ nelayan menyatakan tidak mencari informasi teknologi penangkapan ikan. Hal ini dengan alasan bahwa para nelayan tidak ada waktu untuk mencari informasi. Bagi nelayan sumber informasi teknologi baru penangkapan ikan diperoleh dari tetangga/sesama nelayan, yaitu sebesar 76,\% dan sebesar 23,3\% informasi teknologi penangkapan ikan diperoleh dari media televisi. Hal ini mengindikasikan bahwa nelayan memiliki tingkat kosmopolitan yang relatif rendah dalam mencari informasi teknologi. Keadaan ini ditunjukkan oleh masih sedikitnya pemanfaatan media massa dalam penggunaan teknologi penangkapan ikan.

\section{Hubungan nelayan dengan pengolah ikan/pengumpul}

Hubungan nelayan dengan pengolah ikan/pengumpul yang berkembang lebih bersifat pola patron client di mana posisi pengolah/pengumpul ikan merupakan patron dan nelayan sebagai client. Artinya pengolah 
ikan/pengumpul berperan sebagai penampung (pasar) hasil tangkapan ikan. Di samping itu pengolah ikan/pengumpul menyediakan modal kerja kepada nelayan yang membutuhkan, dan sebagai imbalannya para nelayan berkewajiban menjual hasil tangkapannya kepada pemberi modal kerja.

Akibat dari mekanisme tersebut daya tawar nelayan sangat lemah dalam menentukan harga ikan tangkapan atau dengan kata lain pengolah ikan/pengumpul lebih dominan dalam menentukan harga ikan tangkapan. Bagi nelayan yang mandiri posisi tawar akan lebih kuat dalam arti nelayan dapat memilih pasar yang yang membeli hasil tangkapannya dengan harga tinggi.

Hasil kajian menunjukkan bahwa ketergnatungan nelayan terhadap pinjaman/modal usaha dari lembaga non formal masih relatif kecil yaitu sebesar 33,3\%. Hal ini dapat dimengerti bahwa dalam hubungan antara nelayan dengan pengolah ikan/pengumpul, nelayan masih memiliki posisi tawar lebih baik dalam menetapkan harga ikan tangkapan. Hubungan nelayan dengan pengolah ikan/pengumpul hanya sebatas pemasaran ikan dan penyediaan modal usaha, belum menyangkut masalah resiko kegagalan usaha nelayan yang dapat terjadi.

\section{Aspek pasar}

Keberhasilan suatu bisnis di pasar sangat dipengaruhi oleh struktur dan karakteristik pasarnya, ada empat karakteristik yang selalu melekat pada pasar yaitu: (1) jumlah dan skala usaha atau partisipan yang terlibat, (2) karakteristik produk yang diperjualbelikan, (3) persyaratan untuk "keluar" atau "masuk" pasar, dan (4) penguasaan informasi oleh partisipan yang terlibat dalam pasar (Limbong dan Sitorus, 1987 dan Kotler dan Gary, 1997). Selanjutnya berdasarkan jumlah partisipasi yang terlibat dan karakteristik produk, pasar dikelompokkan menjadi enam bentuk yaitu: (1) kompetisi murni, (2) monopsoni, (3) oligopsoni murni, (4) oligopsoni, (5) monopoli, dan (6) monopsoni (Limbong dan Sitorus, 1987).

Hasil kajian menunjukkan bahwa pasar yang terjadi di lokasi penelitian adalah bentuk oligopsoni yang membedakan harga dan kualitas produk. Hal ini disebabkan karena pada pasar tersebut hanya terdapat beberapa pengolah ikan dan pengumpul yang menampung hasil tangkapan nelayan. Ini tejadi karena jumlah nelayan yang menjual produknya jauh lebih banyak dari pengolah ikan dan pengumpul, sehingga struktur pasar yang kompetitif tidak tercipta.

\section{Pendapatan nelayan}

Pendapatan kotor dikurangi dengan biaya-biaya yang harus dikeluarkan (di luar biaya investasi) akan diperoleh pendapatan bersih per sekali melaut 
dari satu unit armada. Hasil penelitian menunjukkan bahwa pendapatan bersih nelayan sebesar Rp3.510.000,00/bulan.

\section{Rancangan Model Pengembangan Sumber Daya Nelayan}

Pengembangan sumber daya manusia merupakan investasi terpenting yang mungkin dilakukan oleh suatu organisasi. Karena dengan pengembangan sumber daya manusia dan sekaligus peningkatan kualitas akan memberikan sumbangan yang cukup besar bagi peningkatan pertumbuhan dan kemajuan ekonomi suatu negara. Demikian halnya pada pengembangan sumber daya nelayan dan peningkatan kualitas akan memberikan kontribusi yang cukup besar bagi peningkatan ekonomi perikanan.

\section{Model Pelatihan}

Pelatihan bagi nelayan dalam pengkajian ini lebih cenderung pada pendekatan "training for impact", walaupun tidak mengabaikan pendekatan lainnya. Dalam pendekatan pelatihan ini ada beberapa sinyalemen/kritik tentang hasil pelatihan yaitu: (1) hasil pelatihan kurang dapat memenuhi kebutuhan bisnis, permasalahan, dan peluang bisnis ke depan, (2) efektivitas biaya per output dinilai masih kurang seimbang dengan performansi alumni pelatihan, (3) lemahnya kerja sama antara perancang program pelatihan dengan dunia usaha dalam merancang suatu pelatihan yang "bussiness oriented". Dengan adanya kritik tersebut diharapkan pendekatan "training for impact" dapat menjawab semua kelemahan, sekaligus memperbaiki kinerja alumni pelatihan. Selanjutnya dengan menggunakan training for impact, maka pelatihan lebih dititikberatkan pada project driven, bukan penekanan pada curriculum based.

Berdasarkan hasil kajian ini, terdapat informasi yang penting dan dapat dipakai dalam penyusunan program latihan berdasarkan pendekatan training for impact. Hasil kajian menunjukkan bahwa sebanyak $100 \%$ nelayan mengatakan memerlukan pelatihan mengenai penangkapan ikan dengan teknologi baru, teknik melihat titik keberadaan ikan terbanyak, dan memprediksi keadaan cuaca, serta pelatihan mengenai teknik pengelolaan ikan. Di samping itu diketahui bahwa kesejajaran tersebut dapat diupayakan melalui perbaikan sarana permodelan, perbaikan sistem penetapan harga dan pelatihan perbaikan kemampuan manajerial.

Walaupun demikian tidak seluruh kebutuhan tersebut dapat diatasi dengan menggunakan pelatihan. Oleh karena itu, selain melalui pelatihan maka dibutuhkan penyempurnaan kelembagaan (khususnya yang menyangkut pasar dan standar harga). Dari segi kemampuan manajerial, aspek manajerial harus segera diperbaiki adalah unsur perencanaan sebelum melaut, komunikasi dan organisasi serta unsur evaluasi setelah melaut. Hal ini ditunjukkan oleh pernyataan nelayan dengan nilai persentase yang rendah. 
Selain itu pelatihan yang terkait dengan aksesibilitas terhadap lembaga pemodalan perlu diadakan, khususnya yang menyangkut prosedur dan persyaratan kredit perbankan. Dari segi teknis, pelatihan yang perlu diberikan pada umumnya menyangkut grading dan hadling hasil tangkapan. Dengan memperbaiki hal tersebut diharapkan kemampuan manajerial nelayan menjadi semakin baik.

\section{Model Pendidikan}

Tingkat pendidikan yang dimiliki oleh nelayan merupakan faktor yang penting sebagai penunjang keberhasilan nelayan dalam bekerja, di samping faktor pengalaman sebagai nelayan. Karena faktor pendidikan formal dan pengalaman nelayan akan mempengaruhi pola pikir, tindakan dan perbuatan terhadap segala sesuatu yang berkaitan dengan usaha penangkapan ikan oleh nelayan. Hasil kajian menunjukkan bahwa rata-rata pendidikan nelayan adalah tamatan SLTP dan sedikit sekali yang bisa menamatkan pendidikan menengah atas dan tidak ada yang menamatkan pendidikan tinggi. Berdasarkan hasil kajian ini, menunjukkan bahwa pernyataan nelayan sebesar $100 \%$ perlu dan membutuhkan pendidikan pertanian dalam rangka meningkatkan keterampilan upaya penangkapan ikan.

Mengingat pentingnya peran pendidikan, maka pengembangan sumber daya nelayan melalui jalur ini perlu dilakukan. Jalur ini tidak dapat dilakukan segera tetapi membutuhkan waktu dan strategi yang tepat. Salah satu upaya yang dapat dilakukan adalah dengan jalan mengintegrasikan pendidikan menengah (setingkat SLTP) dengan pendidikan pertanian, atau dikenal sebagai pendidikan menengah pertanian bagi petani-nelayan.

\section{SIMPULAN DAN SARAN}

\section{Simpulan}

Hasil penelitian menunjukkan bahwa nelayan secara umum berada pada usia produktif dengan tipologi keluarga inti (nuclear family); lebih dari separuh nelayan mempunyai tingkat pendidikan jenjang SLTP; pengalaman nelayan dikategorikan cukup lama yaitu 18,26 tahun; nelayan mempunyai motivasi untuk tetap bekerja sebagai nelayan dan memiliki hierarki rasa kasih sayang (safety needs) sebesar 60\%; kemampuan teknis dan manajerial yang dimiliki nelayan secara umum sudah cukup baik namun aspek manajerial nelayan masih kurang baik.

Sebagian besar nelayan memiliki aksesibilitas yang tinggi terhadap sarana penangkapan ikan, namun hanya sedikit nelayan yang memanfaatkan pinjaman modal dari lembaga non formal, sebagian besar nelayan aktif mencari informasi mengenai teknologi penangkapan ikan, hubungan nelayan dengan pengolah ikan/pengumpul bersifat pola patron client, pasar yang terbentuk di 
lokasi penelitian adalah pasar oligopsoni, dan pendapatan bersih nelayan dapat dikategorikan cukup. Terdapat dua alternatif model pengembangan sumber daya nelayan berwawasan agribisnis yaitu model pelatihan dengan pendekatan training for impact dan model pendidikan.

\section{Saran}

Dalam rangka memperkuat posisi nelayan dalam kemitraan seyogyanya pengolah ikan (tengkulak) menyerahkan sedikit "hak"nya untuk dikelola oleh nelayan, yang mencakup pemberian kebebasan kepada nelayan untuk mengakses sarana penangkapan dan pemodalan tanpa tergantung sepenuhnya pada pengolah ikan (tengkulak) sehingga tercipta kemandirian nelayan yang semakin baik.

Sebaiknya model pengembangan sumber daya nelayan yang dilakukan didasarkan pada konsep "dua sistem", memadukan sistem pengembangan sumber daya nelayan ke dalam suatu unit agribisinis di dalam satu lokasi tertentu yang memiliki sarana dan prasarana yang memadai dengan lebih banyak melibatkan swasta. Dengan demikian diharapkan penyiapan dan peningkatan kualitas sumber daya nelayan melalui pelatihan dan pendidikan dapat terlaksana. 


\section{DAFTAR PUSTAKA}

Anna, E. R. Ndruru. 2004. Analisis Fungsi Produksi, Pendapatan, dan Pemasaran Kentang di Huta Simallopuk, Desa Parbuluan, Kecamatan Parbuluan, Kabupaten Dairi, Sumatera Utara. Skripsi Fakultas Pertanian Universitas Bengkulu.

Bailey, K.D. 1987. Methods of Social Research. Third edition. The Free Press, New York.

Dane, F. C. 1990. Research Methods. Brooks and Cole Publishing Company, California.

Garrett and Silver. 1968. Production Management Analysis, Second Edition. Harcourt Brace Jovanovich. International Edition.

Kotler, P. dan A. Gary. 1997. Dasar-dasar Pemasaran. Prenhallindo. Jakarta.

Limbong, W.H. dan P. Sitorus. 1987. Pengantar Tataniaga Pertanian, Ilmu-ilmu Sosial Ekonomi Pertanian. Fakultas Pertanian IPB, Bogor.

Mardani, A. 2009. Analisis Fungsi Produksi dan Efisiensi Alokatif Usahatani Jagung di Desa Riak Siabun, Kecamatan Sukaraja, Kabupaten Seluma, Provinsi Bengkulu. Skripsi Fakultas Pertanian, Universitas Bengkulu.

Mardikanto, T. 2010. Komunikasi Pembangunan. UNS Press. Surakarta, Jawa Tengah.

Meleong, L. J. 2004. Metodologi Penelitian Kualitatif. Edisi 1 cetakan ke-18. Remaja Rosdakarya. Bandung.

Mubyarto. 1989. Pengantar Ekonomi Pertanian. LP3ES. Jakarta.

Purwoko, A. 2009. Dasar-dasar Penyuluhan Pertanian. BPFB Universitas Bengkulu.

Sukandar rumidi. 2004. Metodologi Penelitian. Petunjuk Praktis untuk Peneliti Pemula. Cetakan ke-2. Gadjah Mada University Press. Yogyakarta.

Thoha, M. 1995. Perilaku Organisasi, Konsep Dasar dan Aplikasinya. Raja Grafindo Persada. Jakarta.

228 | Sriyoto dan Bambang Sumantri, Pengembangan Model Sumberdaya ... 